\title{
A CLINICAL STUDY TO EVALUATE THE EFFECT OF DADRUGHNA PATRA TAILA IN DADRU KUSHTA
}

\author{
Lakshmi S P ${ }^{1}$, Harini $\mathbf{A}^{2}$ \\ ${ }^{1,2}$ PG Scholar, Associate Professor, Department of Dravyaguna, \\ Shri Dharmasthala Manjunatheshwara College of Ayurveda and Hospital, Hassan-573201
}

Corresponding author: Lakshmi S P, PG Scholar, Department of Dravyaguna, Shri Dharmasthala Manjunatheshwara College of Ayurveda and Hospital, Hassan-573201

Article DOI: https://doi.org/10.36713/epra8661 DOI No: 10.36713/epra8661

\begin{abstract}
Introduction: All the skin diseases in Ayurveda have been classified under the broad heading, "Kushta". Dadru is one among Kushta. It involves the clinical features like kandu, raga, pidaka, utsannamandala. Dadru kushta mostly simulates with 'Dermatophytosis' commonly referred to as ringworm which is highly contagious. In this study an effort has been made to evaluate the Dadrughna karma (Antifungal activity) of the oil prepared from Dadrughna (Cassia alata Linn) leaves.

Materials and methods: In the present study, action of Dadrughna (Cassia alata Linn) patra taila on Dadru kushta was evaluated in 32 subjects who were treated with Dadrughna patra taila as an external application twice a day for 30 days and follow up was done on 45th day. Assessment was done for subjective parameter-itching and objective parameters-distribution of lesion, severity of inflammation, extent of lesion.

Results: The effect of therapy was assessed before treatment, $15^{\text {th }}$ day, $30^{\text {th }}$ day of treatment and follow up was done on $45^{\text {th }}$ day. The results were statistically analyzed; it showed significant changes in subjective parameter-itching $(p<0.001)$ and Objective parameters- distribution of lesion $(p<0.001)$, severity of inflammation $(p<0.001)$, extent of lesion $(p<0.001)$.

Discussion and conclusion: The external application of Dadrughna patra taila applied for 30 days has helped in reduction of itching, distribution of lesion, extent of inflammation and severity of inflammation where the taila was found more effective in reducing itching when compared to other symptoms

KEY WORDS: Dadru kushta, Dermatophytosis, Dadrughna (Cassia alata Linn), Dadrughna patra taila
\end{abstract}

\section{INTRODUCTION}

All the skin diseases in Ayurveda have been classified under the broad heading, "Kushta" which are further classified into Mahakushta and Kshudrakushta. ${ }^{1}$ Dadru is one among Kushta. Dadru kushta is mentioned under both Mahakushta and Kshudrakushta by different acharya $a^{2,3,4}$ It involves the clinical features like kandu, raga, pidaka, utsannamandala and it is also mentioned as anushangini ${ }^{5}$
On the basis of clinical appearance, Dadru kushta mostly simulates with 'Dermatophytosis' The Dermatophytes are a group of closely related fungi that have the capacity to invade keratinized tissue (skin, hair and nails) of humans and other animals to produce an infection, Dermatophytosis, commonly referred to as ringworm which is highly contagious. The infections caused by a dermatophyte (species of fungi belonging to the genera Trichophyton, Microsporum or Epidermophyton) are referred to as Tinea. Ringworm 
involving body, arms and legs is termed as Tinea corporis ${ }^{6}$.

According to WHO, the prevalence rate of superficial mycotic infection worldwide has been found to be $20-25 \%$. The Tinea infections are prevalent globally but they are common in tropics and may reach epidemic proportions in geographical areas with higher humidity, over population and poor hygienic living conditions ${ }^{7}$.

In the context of Dadru Kushta, Bahirparimarjana type of chikitsa $^{8}$ is mentioned which includes Taila kalpana also. Fat/water soluble active constituents can be extracted easily in this method. Hence in the current study, taila of the leaves of Dadrughna (Cassia alata Linn) has been selected to assess the Dadrughna activity. Dadrughna botanically identified as Cassia alata Linn belonging to the family Caesalpiniaceae is an ornamental shrub, distributed from tropical America to India. It is commonly known as Ringworm senna. This plant is used as a folklore medicine for the treatment of skin diseases like Scabies, Eczema, Pruritus, Ringworm and other fungal infections.

\section{AIMS AND OBJECTIVES}

To evaluate the Dadrughna karma of Dadrughna (Cassia alata Linn) patra taila

\section{MATERIALS AND METHODS}

Source of data: Patients attending the Outpatient department (OPD) of Skin at a tertiary Ayurveda healthcare centre attached to a teaching institute, situated at the district headquarters in South India Ethical Committee Approval Number SDM/IEC/24/2019

Clinical Trial Registry of India CTRI/2019/09/021113

\section{CRITERIA OF EVALUATION}

\section{Diagnostic criteria}

For diagnosis detailed medical history and physical examination was done according to both Ayurvedic and Modern clinical methods

Inclusion criteria

1. Patients clinically diagnosed with tinea infection.

2. Direct microscopy skin test positive.

3. Aged over 18 years and of any gender.

4. Patients who are willing to be a part of this study and sign the informed consent form.

\section{Exclusion criteria:}

5. Patients associated with other types of Kushta.

6. Systemic disorders like uncontrolled Diabetes and uncontrolled hypertension

7. Use of corticoids, cytostatics, antibiotics or immune depressing drugs

\section{STUDY DESIGN}

The present study was an open label, single arm, clinical study conducted in a tertiary Ayurveda healthcare centre attached to a teaching institute, situated at the district headquarters in Hassan, Karnataka. 32 patients suffering from Dadru kushta who signed the informed consent form and who fulfilled the inclusion criteria for the study were selected using convenience / purposive sampling technique and treated with the external application of Dadrughna(Cassia alata Linn.) patra taila

\section{DOSAGE AND DRUG ADMINISTRATION}

Drug: Dadrughna patra taila

Dosage: Quantity sufficient

Mode of administration: External application

Duration: 30 days

\section{ASSESSMENT CRITERIA}

Assesment will be done on $15^{\text {th }}, 30^{\text {th }}$ and $45^{\text {th }}$ day of the treatment. Assesment tables are given below

Subjective parameter: Assessment of itching as per pruritus severity scale

\begin{tabular}{|c|c|c|c|}
\hline $\begin{array}{c}\text { Sl } \\
\text { No }\end{array}$ & Questions & Possible answers & Scorings \\
\hline 1. & $\begin{array}{l}\text { How often did you feel pruritus within the last } 3 \\
\text { days? }\end{array}$ & $\begin{array}{l}\text { (i) All time } \\
\text { (ii) All morning/afternoon/evening/night long } \\
\text { itching episodes } \\
\text { (iii) Occasionally short itching episode }\end{array}$ & $\begin{array}{c}3 \text { points } \\
2 \text { points } \\
1 \text { point }\end{array}$ \\
\hline 2. & $\begin{array}{l}\text { Did pruritus hinder your ability to do simply } \\
\text { things, like watching TV, hearing music, etc.? }\end{array}$ & $\begin{array}{l}\text { (i) Yes } \\
\text { (ii) No }\end{array}$ & $\begin{array}{l}1 \text { point } \\
0 \text { points }\end{array}$ \\
\hline 3. & $\begin{array}{l}\text { Did you feel irritated or nervous because of } \\
\text { your itching? }\end{array}$ & $\begin{array}{l}\text { (i) Yes } \\
\text { (ii) No }\end{array}$ & $\begin{array}{l}1 \text { point } \\
0 \text { points }\end{array}$ \\
\hline
\end{tabular}




\begin{tabular}{|c|c|c|c|}
\hline 4. & Did your pruritus cause you depressed? & $\begin{array}{l}\text { (i) Yes } \\
\text { (ii) } \mathrm{No}\end{array}$ & $\begin{array}{l}1 \text { point } \\
0 \text { points }\end{array}$ \\
\hline 5. & $\begin{array}{l}\text { Did your pruritus impede your work or learning } \\
\text { abilities? }\end{array}$ & $\begin{array}{l}\text { (i) Yes } \\
\text { (ii) No }\end{array}$ & $\begin{array}{l}1 \text { point } \\
0 \text { points }\end{array}$ \\
\hline 6. & Did you scratch your skin because of itching? & $\begin{array}{l}\text { (i) Yes } \\
\text { (ii) No }\end{array}$ & $\begin{array}{l}1 \text { point } \\
0 \text { points }\end{array}$ \\
\hline 7. & Did scratching bring you relief? & $\begin{array}{l}\text { (i) Yes } \\
\text { (ii) No }\end{array}$ & $\begin{array}{c}0 \text { points } \\
1 \text { point }\end{array}$ \\
\hline 8. & Were you able to refrain from scratching? & $\begin{array}{l}\text { (i) Yes } \\
\text { (ii) No }\end{array}$ & $\begin{array}{l}0 \text { points } \\
1 \text { point }\end{array}$ \\
\hline 9. & $\begin{array}{c}\text { Did you wake up during last night because of } \\
\text { pruritus? }\end{array}$ & $\begin{array}{l}\text { (i) No } \\
\text { (ii) Yes, 1-2 times } \\
\text { (iii) Yes, 3-4 times } \\
\text { (iv) Yes, } 5 \text { and more times }\end{array}$ & $\begin{array}{l}0 \text { points } \\
1 \text { point } \\
2 \text { points } \\
3 \text { points } \\
\end{array}$ \\
\hline 10. & $\begin{array}{l}\text { Could you assess the severity of your pruritus } \\
\text { within last } 3 \text { days? }\end{array}$ & $\begin{array}{l}\text { (i) Very mild } \\
\text { (ii) Mild } \\
\text { (iii) Moderate } \\
\text { (iv) Severe } \\
\text { (v) Very severe }\end{array}$ & $\begin{array}{l}1 \text { point } \\
2 \text { points } \\
3 \text { points } \\
4 \text { points } \\
5 \text { points } \\
\end{array}$ \\
\hline 11. & Could you indicate pruritus location? & $\begin{array}{l}\text { (i) Single locations of pruritus } \\
\text { (ii) Large body areas } \\
\text { (iii) Generalized pruritus }\end{array}$ & $\begin{array}{l}1 \text { point } \\
2 \text { points } \\
3 \text { points }\end{array}$ \\
\hline 12. & $\begin{array}{l}\text { Are excoriations or other scratch lesions } \\
\text { present? }\end{array}$ & $\begin{array}{l}\text { (i) Yes } \\
\text { (ii) No }\end{array}$ & $\begin{array}{l}1 \text { point } \\
0 \text { points }\end{array}$ \\
\hline
\end{tabular}

\section{OBJECTIVE PARAMETERS}

\section{Distrubution of lesions:}

1. Mild: involvement of only one region of the body

2. Moderate: involvement of more than one region of the body and less than or equal to three regions of the body

3. Disseminated: involvement of more than three regions of the body

\section{Severity of lesions:}

\begin{tabular}{|c|c|c|}
\hline SI No & Inflammation & Severity \\
\hline 1 & Scaly plaque-like lesions with mild inflammation & 1 point \\
\hline 2 & Typical "ringworm" lesions with an annular appearance & 2 points \\
\hline 3 & Vesicular or exudative lesions with intense inflammation & 3 points \\
\hline
\end{tabular}

\section{Extent of lesions:}

\begin{tabular}{|c|c|c|}
\hline SI No & Inflammation & Severity \\
\hline 1 & Lesions $<3 \mathrm{~cm}$ in diameter & 1 point \\
\hline 2 & Lesions $3-6 \mathrm{~cm}$ in diameter & 2 points \\
\hline 3 & Lesions $>6 \mathrm{~cm}$ in diameter & 3 points \\
\hline
\end{tabular}




\section{STATISTICAL ANALYSIS}

- Friedman's test was applied to analyze the significance of change in Subjective and objective parameters (within the group)

- Wilcoxon's sign rank test was done for post Hoc analysis with Bonferroni correction on parameters which show significance in Friedman's test, to interpret the time of significant change

\section{OBSERVATION}

In the present study total 58 subjects were screened, out of which 35 subjects were registered for the study, among them 32 subjects completed the study and 3 were dropped out

Among 35 completed subjects maximum from the age group of 21-40 $(n=20)$ and predominance of males $(n=21)$ over females was found. Majority of the subjects were married $(\mathrm{n}=27)$. Diet wise distribution showed maximum were having non veg diet $(n=33)$. Considerable number of subjects $(n=19)$ were having family history

\section{RESULTS}

In the present study total 58 subjects were screened, out of which 35 subjects were registered for the study, among them 32 subjects completed the study and 3 were dropped out

32 subjects were given Dadrughna patra taila to apply externally twice a day for a period of 30 days

Friedman's test and Wilcoxon's sign rank test were conducted (Table 1- 8)

\section{DISCUSSION}

Effect of therapy on Subjective parameter:

Based on 12-item Pruritus severity scale

It's a validated scale created for the assessment of pruritus severity which consists of 12 questions. The questions are mainly related to pruritus intensity, pruritus extent and duration and influence of pruritus on concentration and patient psyche.

\section{Pruritus intensity}

All the 32 patients had the complain of pruritus with varying intensity. Assessment regarding severity of pruritus $(k a n d u)$ was done before treatment and on $15^{\text {th }}$ day, $15^{\text {th }} \& 30^{\text {th }}$ day, $30^{\text {th }} \& 45^{\text {th }}$ day (follow up). On application of statistics Wilcoxon sign rank test with post hoc test with Bonferroni correction -0.0125 , the obtained result was statistically significant in all the 4 occasions with $\mathrm{P}$ value $<0.001$. No patients were distributed in positive rank in any of the occasions showed that there was no aggravation of kandu. Further on comparison of reduction in severity of kandu between before treatment and follow up, 32 patients were distributed in negative rank which shows that there was reduction in severity of kandu in all the patients after application of Dadrughna patra taila.

\section{Pruritus Extent and Duration}

Most of the patients had the complain of long itch episodes all morning/afternoon/evening/night. Assessment regarding extent and duration of pruritus $(k a n d u)$ was done before treatment and on $15^{\text {th }}$ day, $15^{\text {th }}$ $\& 30^{\text {th }}$ day, $30^{\text {th }} \& 45^{\text {th }}$ day (follow up). On application of statistics Wilcoxon sign rank test with post hoc test with Bonferroni correction -0.0125 , the results were statistically significant when compared to before treatment $\& 15^{\text {th }}$ day, $15^{\text {th }}$ day $\& 30^{\text {th }}$ day with $p$ value $<0.001$. When compared to $30^{\text {th }}$ day and follow up, there was reduction observed in extent and duration of kandu but statistically the result was non-significant with $\mathrm{p}$ value 0.025 . However the result was significant when compared to before treatment and follow up with $\mathrm{p}$ value $<0.001$ with 32 patients distributed in negative rank which shows that there was reduction in extent and duration of kandu in all the patients after application of Dadrughna patra taila.

As there is no classical reference available on Rasapanchaka of Dadrughna (Cassia alata Linn) patra, an attempt is made to discuss the results of present study with the help of previous supportive research studies.

The specific mechanism of itching due to dermatophytoses is still unknown. In general mechanisms of any infection induced itch can be direct through the neuronal recognition of PAMPs. Neuronal activation may also be indirect, in particular through immune cells that are activated during infection. These cells release cytokines, lipids and other inflammatory mediators in response to pathogens that then sensitize neurons. Pathogenic infections may also indirectly cause itch through other mechanisms such as the induction of oxidative stress. Recent work has shown that anti-oxidants are potent modulators of acute and chronic itch and thus could be useful in the treatment of infectious itch ${ }^{9}$. Previous research studies have been proved that Cassia alata leaf has strong inhibitory action against dermatophytes that cause ringworm. The phytoconstituents claimed to have antifungal properties are anthracene derivatives, chrysophanol, chrysophanic acid, crude anthraquinones, rhein and aloe-emodine. Thus Dadrughna patra taila is potential enough to reduce itching by inhibiting the activities of dermatophytes. Owing to the role of anti-oxidants in 
fungal infections, based on previous research study it is evidenced that the Cassia alata possess strong antioxidant activity, as it contains good quantity of phenols, vitamin-C, vitamin A, flavonoids, caretenoids and anthraquinone. ${ }^{10}$

\section{Concentration and Patient Psyche}

The questions based on concentration and patient psyche had covered the effect of pruritus on patient's learning ability, irritability, nervousness etc. Assessment was done before treatment and on $15^{\text {th }}$ day, $15^{\text {th }} \& 30^{\text {th }}$ day, $30^{\text {th }} \& 45^{\text {th }}$ day (follow up). On application of statistics Wilcoxon sign rank test with post hoc test with Bonferroni correction -0.0125 , the results were statistically significant when compared to before treatment $\& 15^{\text {th }}$ day with $\mathrm{p}$ value $<0.001$. When compared to $15^{\text {th }}$ and $30^{\text {th }}$ day, $30^{\text {th }}$ day and follow up, there was reduction observed but statistically the result was non-significant. However the result was significant when compared to before treatment and follow up with $\mathrm{p}$ value $<0.001$ which shows that there was reduction in complains related to concentration, irritability, nervousness etc.

Itch is a complex sensory phenomenon that incorporates discriminative, cognitive, motivational and affective components. Recent studies have highlighted that most of the itchy skin conditions are associated with higher rates of stress, anxiety, depression leading to major deficits in quality of life. In turn, stress and anxiety exacerbate itch, leading to a vicious cycle that affects patient behavior (scratching) and worsens disease prognosis ${ }^{11}$. In the present study, there was significant result for the complaints related to stress and anxiety even on the $15^{\text {th }}$ day of application of oil. This might be because of reduction of severity of itching in most of the patients on the $15^{\text {th }}$ day of treatment as shown in the above results.

\section{Effect of therapy on Objective Parameters Distribution of lesion}

Majority of patients were having distribution of lesions in more than 1 region and less than or equal to 3 regions of the body. Assessment regarding distribution of lesions was done before treatment and on $15^{\text {th }}$ day, $15^{\text {th }} \& 30^{\text {th }}$ day, $30^{\text {th }} \& 45^{\text {th }}$ day (follow up). On application of statistics Wilcoxon sign rank test with post hoc test with Bonferroni correction -0.0125 , the result was non-significant when compared to before treatment and $15^{\text {th }}$ day with $\mathrm{p}$ value 0.317 and no patient was distributed in negative rank hence there was no reduction in the distribution of lesions in any of the patients. When compared to $15^{\text {th }}$ day and $30^{\text {th }}$ day, there was reduction observed and 5 patients were distributed in negative rank but the result was statistically non significant with $\mathrm{p}$ value 0.025 . Further the obtained results were statistically significant when compared to $30^{\text {th }}$ day and follow up, before treatment and follow up with $\mathrm{p}$ value $<0.001,8$ and 13 patients were distributed in negative rank respectively which shows that there was reduction in distribution of lesions after application of Dadrughna patra taila

In the present study, the results were nonsignificant for 30 days of treatment and even after treatment only 13 patients showed the reduction of distribution of lesions. As the disease is contagious in nature, the important factor in the spread of this infection is the scratching which develops due to the local reaction between the fungus and the body's immune system. Whenever a patient scratches the lesion, some fungal particles stick to the fingers or the instruments used for scratching and get dislodged to a new site where the person touches after that. This may be considered as one of the reasons for delay in cure of the dermatophytoses.

\section{Severity of Inflammation}

All the 32 patients had typical ringworm lesions with annular appearance. Assessment was done before treatment and on $15^{\text {th }}$ day, $15^{\text {th }} \& 30^{\text {th }}$ day, $30^{\text {th }} \& 45^{\text {th }}$ day (follow up). On application of statistics Wilcoxon sign rank test with post hoc test with Bonferroni correction -0.0125 , the result was non- significant when compared to before treatment and $15^{\text {th }}$ day with $\mathrm{p}$ value 1.000 and no patient was distributed in negative rank hence there was no reduction in the distribution of lesions in any of the patients. When compared to $15^{\text {th }}$ day and $30^{\text {th }}$ day, there was reduction observed and 10 patients were distributed in negative rank but the result was statistically non significant with $\mathrm{p}$ value 0.002 . Further the obtained results were statistically significant when compared to $30^{\text {th }}$ day and follow up, before treatment and follow up with $\mathrm{p}$ value $<0.001,12$ and 21 patients were distributed in negative rank respectively which shows that there was reduction in severity of inflammation after application of Dadrughna patra taila.

Previous research studies have revealed that Cassia alata leaves extract have been proven to have effective anti-inflammatory action. Rhein is one of the major chemical constituents found in Cassia alata. According to a previous study pre-treatment with rhein on $t$-BHP induced inflammation in human keratinocytes showed that the chemical constituent could diminish the inflammatory responses such as production of TNF- $\alpha$ and IL-8 and these effects occurred via suppression of ROS production ${ }^{12}$, thus 
supporting the anti-inflammatory action of Dadrughna patra taila.

\section{Extent of Lesion}

Majority of patients had lesions measuring $3 \mathrm{~cm}$ $-6 \mathrm{~cm}$. Assessment was done before treatment and on $15^{\text {th }}$ day, $15^{\text {th }} \& 30^{\text {th }}$ day, $30^{\text {th }} \& 45^{\text {th }}$ day (follow up). On application of statistics Wilcoxon sign rank test with post hoc test with Bonferroni correction -0.0125 , the result was non- significant when compared to before treatment and $15^{\text {th }}$ day with $\mathrm{p}$ value 1.000 and no patient was distributed in negative rank hence there was no reduction in the extent of lesions in any of the patients. Further the obtained results were statistically significant when compared to $15^{\text {th }}$ day $\& 30^{\text {th }}$ day, $30^{\text {th }}$ day $\&$ follow up, before treatment $\&$ follow up with $\mathrm{p}$ value $<0.001$ and in the last occasion 31 patients were distributed in negative rank which shows that there was reduction in extent of lesion after application of Dadrughna patra taila.

The dermatophyte invades the uppermost nonliving keratinized layer of the skin namely the stratum corneum, produces an exoenzyme keratinase and induces inflammatory reaction at the site of infection. Inflammation causes the pathogen to move away from the site of infection and take residence at a new site. This movement of the organism away from the infection site produces classical ringed lesion ${ }^{13}$. The diameter of the lesion varies according to strength of the infecting dermatophyte and immunity of the host. In the present study the reduction in the size of the lesion is due to anti-fungal and anti-inflammatory action of phytoconstituents present in Cassia alata as explained previously. But there was delay in the reduction of size of the lesions or no complete reduction in the majority of patients. The reason may be the chronicity of the infection in many of the patients and also due to application of steroid creams previously. Steroid creams can temporarily reduce ringworm symptoms like itching and redness, but they don't kill the dermatophyte. These creams also can make ringworm worse because they weaken the skin's defenses. $^{14}$

\section{PROBABLE MODE OF ACTION}

According to a previous research study, the inhibition of tested clinical dermatophytes by Cassia alata leaf extract confirmed their antifungal activity and this is most likely due to the action of different phytoconstituents present in the leaf extract and a wide range of physiological activity of saponins, alkaloids, carbohydrates, flavonoids, anthraquinones, steroids and tannins. ${ }^{15}$

Anthraquinones, the quinines are aromatic rings with two ketone substitutions. They are ubiquitous in nature and are characteristically highly reactive. The switch between hydroquinone and quinone occurs easily through redox reactions. In addition to providing a source of stable free radicals, quinines are known to complex irreversibly with nucleophilic amino acids in protein often leading to inactivation of the protein and loss of function thus acting as anti-fungal.

Tannins are found in almost every part: bark, wood, leaves, fruits and roots of Cassia alata. The tannins present in the leaf extract of Cassia alata were believed to act on skin infections by coagulating the cell wall proteins. According to number of studies, Tannins can be toxic to filmentous fungi, yeast, bacteria.

Saponins are the surface active agents which interfere with or alter the permeability of the cell. Saponins were reported as major components acting as antifungal secondary metabolite.

Flavonoids are phenolic in nature and acts as cytoplasmic poisons. Flavonoids are also hydroxylated phenolic substances but occur as a C6-C3 unit linked to an aromatic ring. Their activity is probably due to their ability to complex with extracellular and soluble proteins and to complex with fungal cell walls. ${ }^{16}$

A previous research study confirms that there are antifungal properties in the crude extract of Cassia alata leaf and this activity may be due to the presence of chrysophanol in the leaf extract. The study states that the reduction in the growth of dermatophytes (3 Trichophyton spp, Microsporum gypsum, and Microsporum canis) was possibly due to interference by active principles of the extract. Such interference may be at the biosynthetic level. Dermatophytes parasitize keratinized tissue such as the horny layer of the epidermis, hair and nails. It exists in either a hyphal form or conidial form. Therefore in this the susceptibilities of the conidia to drugs were examined. Under a light microscopy study, control or untreated culture showed many smooth walled and regularly shaped macroconidia, whereas the treatment culture showed the shrunken and collapsed macroconidia. This phenomenon could be due to the leakage of the cell wall or perhaps some alteration in the membrane permeability and resulting in the loss of cytoplasm. This could lead to loss in rigidity of the macroconidia and finally cause the death of the cells, thus proving the fungicidal activity of Cassia alata. ${ }^{17}$

Thus a handful of research studies provide an insight into the usage of the plant Cassia alata in 


\section{SJIF Impact Factor 2021: 8.013| ISI I.F.Value:1.241| Journal DOI: 10.36713/epra2016 ISSN: 2455-7838(Online) EPRA International Journal of Research and Development (IJRD)

traditional treatment of diseases associated with fungal infections.

\section{REFRENCES}

1. Sharma $P V$, Charaka samhita of Agnivesha with

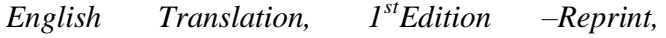
Chaukhambha Orirntalia Varanasi, vol-2, 2008:183

2. Sharma $P V$, Charaka samhita of Agnivesa with English Translation , $1^{\text {st }}$ Edition -Reprint Chaukhambha Orirntalia Varanasi vol-2,2008:184

3. Astanga Sangraha of sarvanga sundari vyakhyaya samhita sutrasthana-prathama bhaga by shri. Pandita lalachandra shastri vaidya, edited by vaidaya Ranajitaraya Desai; $3^{\text {rd }}$ edition; shri.Baidyanath Ayurveda Bhavana, pvt. Ltd Nagpur, 1986:137

4. Sushruta samhita of sushruta with the Nibhanhasangraha commentary of shri Dalhanacharya ; and the Nyaya chandrika of shri.Gayadasa Acharya by vaidya. Jadavaji Trikamji Acharya ; $5^{\text {th }}$ edition; Choukambha orientalia, Varanasi. 2005:37

5. Astanga Sangraha of sarvanga sundari vyakhyaya samhita sutrasthana-prathama bhaga by shri. Pandita lalachandra shastri vaidya, edited by vaidaya Ranajitaraya Desai; $3^{\text {rd }}$ edition; shri.Baidyanath Ayurveda Bhavana, pvt. Ltd Nagpur, 1986:140

6. Khanna N, Singh S. Bhutanis color atlas of Dermatology, ed 6, New Delhi; Jaypee brothers medical publishers 2015; 19-25

7. Lakshmnan A, Ganeshkumar $P$, Mohan $S R$, Hemamalini M, Madhavan R. Epidemioloical and clinical pattern of dermatomycoses in rural India. Indian J Med Microbiol [Internet]. 2015 [cited 2019 march 12]:33, Suppl S1:134-6. Availablefrom:http://www.ijmm.org/article.asp?iss $n=0255$ -
0857; year $=2015 ;$ volume $=33 ;$ issue $=5 ;$ spage $=134 ; e$ page $=136$; aulast $=$ Lakshmanan

8. Susruta, Dalhana, Gayadasa. Chikitsa sthana Chapter 9 Kushta Chikitsa In: Acharya Y T, Acharya $N \quad R($ edi.). Susrutasamhita with Nyayachandrika commentary. Reprint 2010 edition. New Delhi: Chaukhambha Sanskrit Samsthan; 2010: p.443

9. Liu T, Ji R R, Emerging role of Toll like receptors in the control of pain and itch. Neurosci Bull 2012, 28: 131-144

10. W F Sule, I O Okonko, $T$ A Joseph et al, In vitro antifungal activity of Senna alata Linn. Crude leaf extract, Research journal of Biological Sciences. 2010; 5(3): 275-284

11. Isaac M, Infection pain and itch, Neurosci. 2018; 34(1): 109-119

12. Wadkhien K, Chinpsial $C$ et al, Anti-inflammatory effects of rhein and crude extracts from Cassia alata L. in HaCat cells, ISSN. 2018 12(1): 19-32

13. Suganthi $M$, Pathogenesis and clinical significance of Dermatophytes: A comprehensive review, Innovations in pharmaceuticals and pharmacotherapy (IPP). 4(1), 62-70, 2017

14. Centers for Disease Control and Prevention, Fungal diseases use of steroid creams-Information for the public

15. Damodaran S, Venkataraman S, A study on the therapeutic efficacy of Cassia alata Linn. leaf extract against Pityriasis versicolor, Journal of Ethnopharmacology. 1994; 42, 19-23

16. W F Sule, I O Okonko, T A Joseph et al, In vitro antifungal activity of Senna alata Linn. Crude leaf extract, Research journal of Biological Sciences. 2010; 5(3): 275-284

17. Ibrahim D, Osman $H$, Antimicrobial activity of Cassia alata from Malaysia, Journal of Ethnopharmacology. 1995; 45 (151-156) 
Table: 1 Friedman test for subjective parameter Pruritus Statistical assessment on questionnaire of 'Pruritus severity scale'

\begin{tabular}{|c|c|c|c|c|c|c|}
\hline Parameters & Day & $\mathbf{N}$ & $\begin{array}{c}\text { Mean } \\
\text { rank }\end{array}$ & Chi Square $\left(x^{2}\right)$ & P value & Remarks \\
\hline \multirow{4}{*}{$\begin{array}{l}\text { 'How often did you feel Pruritus } \\
\text { within last } 3 \text { days'? }\end{array}$} & D1 & \multirow{4}{*}{32} & 3.88 & \multirow{4}{*}{77.410} & \multirow{4}{*}{$<0.001$} & \multirow{4}{*}{ Significan } \\
\hline & D15 & & 2.52 & & & \\
\hline & D30 & & 1.92 & & & \\
\hline & D45(FU) & & 1.69 & & & \\
\hline \multirow{4}{*}{$\begin{array}{l}\text { Did pruritus hinder your ability } \\
\text { to do simple things like watching } \\
\text { TV, hearing music,etc?' }\end{array}$} & 1 & \multirow{4}{*}{32} & 3.69 & \multirow{4}{*}{68.348} & \multirow{4}{*}{$<0.001$} & \multirow{4}{*}{ Significan } \\
\hline & 15 & & 2.44 & & & \\
\hline & 30 & & 1.94 & & & \\
\hline & Follow up(45) & & 1.94 & & & \\
\hline \multirow{4}{*}{$\begin{array}{l}\text { 'Did you feel irritated or nervous } \\
\text { because of your itching?' }\end{array}$} & 1 & \multirow{4}{*}{32} & 3.36 & \multirow{4}{*}{51.814} & \multirow{4}{*}{$<0.001$} & \multirow{4}{*}{ Significan } \\
\hline & 15 & & 2.30 & & & \\
\hline & 30 & & 2.17 & & & \\
\hline & Follow up(45) & & 2.17 & & & \\
\hline \multirow{4}{*}{$\begin{array}{l}\text { 'Did your pruritus cause you } \\
\text { depressed?' } \\
\text { Table: } 43 \text { Friedman test }\end{array}$} & 1 & \multirow{4}{*}{32} & 3.05 & \multirow[b]{4}{*}{33.324} & \multirow{4}{*}{$<0.001$} & \multirow{4}{*}{ Significan } \\
\hline & 15 & & 2.36 & & & \\
\hline & 30 & & 2.30 & & & \\
\hline & Follow up(45) & & 2.30 & & & \\
\hline \multirow{4}{*}{$\begin{array}{l}\text { 'Did your pruritus impede your } \\
\text { learning abilities?' }\end{array}$} & 1 & \multirow{4}{*}{32} & 3.55 & \multirow{4}{*}{63.676} & \multirow{4}{*}{$<0.001$} & \multirow{4}{*}{ Significan } \\
\hline & 15 & & 2.23 & & & \\
\hline & 30 & & 2.11 & & & \\
\hline & Follow up(45) & & 2.11 & & & \\
\hline \multirow{4}{*}{$\begin{array}{l}\text { 'Did you scratch your skin } \\
\text { because of itching?' }\end{array}$} & 1 & \multirow{4}{*}{32} & 3.80 & \multirow{4}{*}{73.457} & & \\
\hline & 15 & & 2.48 & & & \\
\hline & 30 & & 1.92 & & $<0.001$ & Significant \\
\hline & Follow up(45) & & 1.80 & & & \\
\hline & 1 & & 2.81 & & & \\
\hline & 15 & & 2.44 & & & \\
\hline 'Did scratching bring you relief?' & 30 & 32 & 2.38 & 18545 & $<0.001$ & Significant \\
\hline & Follow up(45) & & 2.38 & & & \\
\hline & 1 & & 2.69 & & & \\
\hline & 15 & & 2.44 & & & \\
\hline "Were you able to refrain from & 30 & 32 & 2.44 & 12000 & $<0.001$ & Significant \\
\hline & Follow up(45) & & 2.44 & & & \\
\hline 'Did you wake up during last & 1 & 32 & 3.86 & & & \\
\hline night because of pruritus?' & 15 & 52 & 2.67 & 77.927 & $<0.001$ & Significant \\
\hline
\end{tabular}


SJIF Impact Factor 2021: 8.013| ISI I.F.Value:1.241| Journal DOI: 10.36713/epra2016

ISSN: 2455-7838(Online)

EPRA International Journal of Research and Development (IJRD)

Volume: 6 | Issue: 10 | October 2021

- Peer Reviewed Journal

\begin{tabular}{|c|c|c|c|c|c|c|}
\hline & 30 & & 1.95 & & & \\
\hline & Follow up(45) & & 1.52 & & & \\
\hline \multirow{4}{*}{$\begin{array}{l}\text { 'Could you assess the severity of } \\
\text { pruritus within last } 3 \text { days?' }\end{array}$} & 1 & \multirow{4}{*}{32} & 4.00 & \multirow{4}{*}{92.584} & \multirow{4}{*}{$<0.001$} & \multirow{4}{*}{ Significan } \\
\hline & 15 & & 2.97 & & & \\
\hline & 30 & & 1.80 & & & \\
\hline & Follow up(45) & & 1.23 & & & \\
\hline \multirow{4}{*}{$\begin{array}{l}\text { 'Could you indicate pruritus } \\
\text { location?' }\end{array}$} & 1 & \multirow{4}{*}{32} & 2.59 & \multirow{4}{*}{9.000} & \multirow{4}{*}{$<0.001$} & \multirow{4}{*}{ Significan } \\
\hline & 15 & & 2.59 & & & \\
\hline & 30 & & 2.41 & & & \\
\hline & Follow up(45) & & 2.41 & & & \\
\hline
\end{tabular}

Friedman test for objective parameters

Table: 2 Distribution of lesions

\begin{tabular}{|c|c|c|c|c|c|}
\hline Parameters & $\mathbf{N}$ & Mean rank & Chi Square $\left(\mathbf{x}^{2}\right)$ & P value & Remarks \\
\hline Distribution of lesions D1 & \multirow{4}{*}{32} & 2.80 & \multirow{4}{*}{26.745} & \multirow{4}{*}{$<0.001$} & \multirow{4}{*}{ Significan } \\
\hline Distribution of lesions D15 & & 2.73 & & & \\
\hline Distribution of lesions D30 & & 2.48 & & & \\
\hline Distribution of lesions FU & & 1.98 & & & \\
\hline
\end{tabular}

Table: 3 Severity of inflammation

\begin{tabular}{|c|c|c|c|c|c|}
\hline Parameters & $\mathbf{N}$ & Mean rank & Chi Square $\left(\mathrm{x}^{2}\right)$ & P value & Remarks \\
\hline Severity of inflammation BT & \multirow{4}{*}{32} & 2.98 & \multirow{4}{*}{50.020} & \multirow{4}{*}{$<0.001$} & \multirow{4}{*}{ Significant } \\
\hline Severity of inflammation D15 & & 2.98 & & & \\
\hline Severity of inflammation D30 & & 2.38 & & & \\
\hline Severity of inflammation FU & & 1.66 & & & \\
\hline
\end{tabular}

Table: 4 Extent of lesion

\begin{tabular}{|c|c|c|c|c|c|}
\hline Parameters & $\mathbf{N}$ & Mean rank & Chi Square $\left(\mathbf{x}^{2}\right)$ & P value & Remarks \\
\hline Extent of lesions BT & \multirow{4}{*}{32} & 3.33 & \multirow{4}{*}{77.504} & \multirow{4}{*}{$<0.001$} & \multirow{4}{*}{ Significan } \\
\hline Extent of lesions D15 & & 3.33 & & & \\
\hline Extent of lesions D30 & & 1.95 & & & \\
\hline Extent of lesions FU & & 1.39 & & & \\
\hline
\end{tabular}

Table: 5 Wilcoxon sign rank test for questionnaire of 'Pruritus severity scale'

\begin{tabular}{|c|c|c|c|c|c|c|c|c|c|c|c|c|}
\hline \multirow[b]{2}{*}{ Parameters } & \multirow[b]{2}{*}{ Day } & \multicolumn{3}{|c|}{ Negative ranks } & \multicolumn{3}{|c|}{ Positive ranks } & \multirow[b]{2}{*}{ Ties } & \multirow[b]{2}{*}{ Total } & \multirow{2}{*}{$\begin{array}{c}Z \\
\text { value } \\
\mathbf{N}\end{array}$} & \multirow{2}{*}{$\begin{array}{c}\text { P value } \\
\text { MR }\end{array}$} & \multirow{2}{*}{$\begin{array}{c}\mathbf{R} \\
\mathbf{S R}\end{array}$} \\
\hline & & $\mathbf{N}$ & MR & SR & $\mathbf{N}$ & MR & SR & & & & & \\
\hline \multirow{4}{*}{$\begin{array}{l}\text { 'How often did } \\
\text { you feel Pruritus } \\
\text { within last } 3 \\
\text { days'? }\end{array}$} & $\mathrm{D} 15$ & 25 & 13.0 & 325.00 & 0 & .00 & .00 & 7 & 32 & -5.00 & $<0.001$ & $\mathbf{S}$ \\
\hline & D15-D30 & 11 & 6.00 & 66.00 & 0 & .00 & .00 & 21 & 32 & -3.31 & 1 & $\mathbf{S}$ \\
\hline & D30-FU & 5 & 3.00 & 15.00 & 0 & .00 & .00 & 27 & 32 & -2.23 & $>0$ & NS \\
\hline & D1-FU & 32 & 16.50 & 528.00 & 0 & .00 & .00 & 0 & 32 & -5.18 & $<0.001$ & $\mathbf{S}$ \\
\hline \multirow{4}{*}{$\begin{array}{lr}\text { Did } & \text { pruritus } \\
\text { hinder } & \text { your } \\
\text { ability } & \text { to do } \\
\text { simple } & \text { things } \\
\end{array}$} & D1-D15 & 20 & 10.50 & 210.0 & 0 & .00 & .00 & 12 & 32 & -4.47 & $<0.001$ & $\mathbf{S}$ \\
\hline & D15-D30 & 8 & 4.50 & 36.00 & 0 & .00 & .00 & 24 & 32 & -2.82 & $<0.001$ & $\mathbf{S}$ \\
\hline & D30-FU & 0 & .00 & .00 & 0 & .00 & .00 & 32 & 32 & . 000 & $>0.001$ & NS \\
\hline & D1-FU & 28 & 14.50 & 406.00 & 0 & .00 & .00 & 4 & 32 & -5.29 & $<0.001$ & $\mathbf{S}$ \\
\hline
\end{tabular}

(c) 2021 EPRA IJRD | Journal DOI: https://doi.org/10.36713/epra2016 |www.eprajournals.com |118 | 


\section{SJIF Impact Factor 2021: 8.013| ISI I.F.Value:1.241| Journal DOI: 10.36713/epra2016 ISSN: 2455-7838(Online) \\ EPRA International Journal of Research and Development (IJRD)

\begin{tabular}{|c|c|c|c|c|c|c|c|c|c|c|c|c|}
\hline $\begin{array}{l}\text { like watching } \\
\text { TV, hearing } \\
\text { music,etc?' }\end{array}$ & & & & & & & & & & & & \\
\hline \multirow{4}{*}{$\begin{array}{l}\text { 'Did you feel } \\
\text { irritated } \\
\text { nervous because } \\
\text { of your itching?' }\end{array}$} & D1-D15 & 17 & 9.00 & 153.00 & 0 & .00 & .00 & 15 & 32 & -4.12 & $<0.001$ & $\mathbf{S}$ \\
\hline & D15-D30 & 2 & 1.50 & 3.00 & 0 & .00 & .00 & 30 & 32 & -1.41 & $>0.001$ & NS \\
\hline & D30-FU & 0 & .00 & .00 & 0 & .00 & .00 & 32 & 32 & .000 & $>0.001$ & NS \\
\hline & D1-FU & 19 & 10.00 & 190.00 & 0 & .00 & .00 & 13 & 32 & -4.35 & $<0.001$ & $\mathbf{S}$ \\
\hline \multirow{3}{*}{$\begin{array}{lr}\text { 'Did } & \text { your } \\
\text { pruritus } & \text { cause } \\
\text { you depressed?' }\end{array}$} & D1-D15 & 11 & 6.00 & 66.00 & 0 & .00 & .00 & 21 & 32 & -3.31 & $<0.001$ & $\mathbf{S}$ \\
\hline & D15-D30 & 1 & 1.00 & 1.00 & 0 & .00 & .00 & 31 & 32 & -1.00 & $>0.001$ & NS \\
\hline & D30-FU & 0 & .00 & .00 & 0 & .00 & .00 & 32 & 32 & .000 & $>0.001$ & NS \\
\hline $\begin{array}{l}\text { Table: } 43 \\
\text { Friedman test }\end{array}$ & D1-FU & 12 & 6.50 & 78.00 & 0 & .00 & .00 & 20 & 32 & -3.46 & $<0.001$ & $\mathbf{S}$ \\
\hline \multirow{4}{*}{$\begin{array}{lr}\text { 'Did } & \text { your } \\
\text { pruritus impede } \\
\text { your learning } \\
\text { abilities?' }\end{array}$} & D1-D15 & 21 & 11.00 & 231.0 & 0 & .00 & .00 & 11 & 32 & -4.583 & $<0.001$ & $\mathbf{S}$ \\
\hline & D15-D30 & 2 & 1.50 & 3.00 & 0 & .00 & .00 & 30 & 32 & -1.414 & $>0.001$ & NS \\
\hline & D30-FU & 0 & .00 & .00 & 0 & .00 & .00 & 32 & 32 & .000 & $>0.001$ & $\mathbf{N S}$ \\
\hline & D1-FU & 23 & 12.00 & 276.0 & 0 & .00 & .00 & 9 & 32 & -4.79 & $<0.001$ & $\mathbf{S}$ \\
\hline \multirow{4}{*}{$\begin{array}{lr}\text { 'Did you } & \text { scratch } \\
\text { your } & \text { skin } \\
\text { because } & \text { of }\end{array}$} & D1-D15 & 21 & 11.00 & 231.00 & 0 & .00 & .00 & 11 & 32 & -4.58 & $<0.001$ & $\mathbf{S}$ \\
\hline & D15-D30 & 9 & 5.00 & 45.00 & 0 & .00 & .00 & 23 & 32 & -3.00 & $<0.001$ & $\mathbf{S}$ \\
\hline & D30-FU & 2 & 1.50 & 3.00 & 0 & .00 & .00 & 30 & 32 & -1.41 & $>0.001$ & NS \\
\hline & D1-FU & 32 & 16.50 & 528.00 & 0 & .00 & .00 & 0 & 32 & -5.65 & $<0.001$ & $\mathbf{S}$ \\
\hline \multirow{4}{*}{$\begin{array}{l}\text { 'Did scratching } \\
\text { bring you relief?' }\end{array}$} & D1-D15 & 6 & 3.50 & 21.00 & 0 & .00 & .00 & 26 & 32 & -2.449 & $>0.001$ & NS \\
\hline & D15-D30 & 1 & 1.00 & 1.00 & 0 & .00 & .00 & 31 & 32 & -1.000 & $>0.001$ & NS \\
\hline & D30-FU & 0 & .00 & .00 & 0 & .00 & .00 & 32 & 32 & .000 & $>0.001$ & NS \\
\hline & D1-FU & 7 & 4.00 & 28.00 & 0 & .00 & .00 & 25 & 32 & -2.646 & $<0.001$ & $\mathbf{S}$ \\
\hline \multirow{4}{*}{$\begin{array}{l}\text { 'Were you able } \\
\text { to refrain from } \\
\text { scratching?' }\end{array}$} & D1-D15 & 4 & 2.50 & 10.00 & 0 & .00 & .00 & 28 & 32 & -2.000 & $>0.001$ & NS \\
\hline & D15-D30 & 0 & .00 & .00 & 0 & .00 & .00 & 32 & 32 & .000 & $>0.001$ & NS \\
\hline & D30-FU & 0 & .00 & .00 & 0 & .00 & .00 & 32 & 32 & .000 & $>0.001$ & NS \\
\hline & D1-FU & 4 & 2.50 & 10.00 & 0 & .00 & .00 & 28 & 32 & -2.000 & $>0.001$ & NS \\
\hline \multirow{4}{*}{$\begin{array}{l}\text { 'Did you wake } \\
\text { up during last } \\
\text { night because of } \\
\text { pruritus?' }\end{array}$} & D1-D15 & 23 & 12.00 & 276.00 & 0 & .00 & .00 & 9 & 32 & -4.70 & $<0.001$ & $\mathbf{S}$ \\
\hline & D15-D30 & 13 & 7.00 & 91.00 & 0 & .00 & .00 & 19 & 32 & -3.60 & $<0.001$ & $\mathbf{S}$ \\
\hline & D30-FU & 10 & 5.50 & 55.00 & 0 & .00 & .00 & 22 & 32 & -3.16 & $<0.001$ & $\mathbf{S}$ \\
\hline & D1-FU & 32 & 16.50 & 528.00 & 0 & .00 & .00 & 0 & 32 & -5.09 & $<0.001$ & $\mathbf{S}$ \\
\hline \multirow{4}{*}{$\begin{array}{lr}\text { 'Could } & \text { you } \\
\text { assess } & \text { the } \\
\text { severity } & \text { of } \\
\text { pruritus within } \\
\text { last 3 days?' }\end{array}$} & D1-D15 & 32 & 16.50 & 528.00 & 0 & .00 & .00 & 0 & 32 & -5.578 & $<0.001$ & $\mathbf{S}$ \\
\hline & D15-D30 & 30 & 15.50 & 465.00 & 0 & .00 & .00 & 2 & 32 & -5.477 & $<0.001$ & $\mathbf{S}$ \\
\hline & D30-FU & 17 & 9.00 & 153.00 & 0 & .00 & .00 & 15 & 32 & -4.12 & $<0.001$ & $\mathbf{S}$ \\
\hline & D1-FU & 32 & 16.50 & 528.00 & 0 & .00 & .00 & 0 & 32 & -5.08 & $<0.001$ & $\mathbf{S}$ \\
\hline \multirow{4}{*}{$\begin{array}{l}\text { 'Could you } \\
\text { indicate pruritus } \\
\text { location?' }\end{array}$} & D1-D15 & 0 & .00 & .00 & 0 & .00 & .00 & 32 & 32 & .000 & $>0.001$ & NS \\
\hline & D15-D30 & 3 & 2.00 & 6.00 & 0 & .00 & .00 & 29 & 32 & -1.732 & $>0.001$ & NS \\
\hline & D30-FU & 0 & .00 & .00 & 0 & .00 & .00 & 32 & 32 & .000 & $>0.001$ & NS \\
\hline & D1-FU & 3 & 2.00 & 6.00 & 0 & .00 & .00 & 29 & 32 & -1.732 & $>0.001$ & NS \\
\hline
\end{tabular}

Table: 6 Wilcoxon sign rank test for Distribution of lesions

\begin{tabular}{|c|c|c|c|c|c|c|c|c|c|c|c|}
\hline \multirow{2}{*}{ Parameters } & \multicolumn{3}{|c|}{ Negative ranks } & \multicolumn{3}{|c|}{ Positive ranks } & \multirow{2}{*}{ Ties } & \multirow{2}{*}{ Total } & \multirow{2}{*}{$Z$ value } & \multirow{2}{*}{$P$ value } & \multirow{2}{*}{$\mathbf{R}$} \\
\hline & $\mathbf{N}$ & MR & SR & $\mathbf{N}$ & MR & SR & & & & & \\
\hline D1-D15 & 0 & .00 & .00 & 0 & .00 & .00 & 31 & 32 & -1.000 & $>0.001$ & NS \\
\hline D15-D30 & 5 & 3.00 & 15.00 & 0 & .00 & .00 & 27 & 32 & -2.236 & $>0.001$ & NS \\
\hline D30-FU & 8 & 4.50 & 36.00 & 0 & .00 & .00 & 24 & 32 & -2.828 & $<0.001$ & $\mathrm{~S}$ \\
\hline D1-FU & 13 & 7.50 & 97.50 & 1 & 7.50 & 7.50 & 18 & 32 & -3.207 & $<0.001$ & $\mathrm{~S}$ \\
\hline
\end{tabular}

2021 EPRA IJRD | Journal DOI: https://doi.org/10.36713/epra2016 | www.eprajournals.com |119 | 
SJIF Impact Factor 2021: 8.013| ISI I.F.Value:1.241| Journal DOI: 10.36713/epra2016

ISSN: 2455-7838(Online)

EPRA International Journal of Research and Development (IJRD)

Volume: 6 | Issue: 10 | October 2021

- Peer Reviewed Journal

Table: 7 Wilcoxon sign rank test for Severity of inflammation

\begin{tabular}{|c|c|c|c|c|c|c|c|c|c|c|c|}
\hline \multirow{2}{*}{ Parameters } & \multicolumn{3}{|c|}{ Negative ranks } & \multicolumn{3}{|c|}{ Positive ranks } & \multirow{2}{*}{ Ties } & \multirow{2}{*}{ Total } & \multirow{2}{*}{$Z$ value } & \multirow{2}{*}{ P value } & \multirow{2}{*}{$\mathbf{R}$} \\
\hline & $\mathbf{N}$ & MR & SR & $\mathbf{N}$ & MR & SR & & & & & \\
\hline D1-D15 & 0 & .00 & .00 & 0 & .00 & .00 & 32 & 32 & .000 & $>0.001$ & NS \\
\hline D15-D30 & 10 & 5.50 & 55.00 & 0 & .00 & .00 & 22 & 32 & -3.162 & $<0.001$ & $\mathrm{~S}$ \\
\hline D30-FU & 12 & 6.50 & 78.00 & 0 & .00 & .00 & 20 & 32 & -3.217 & $<0.001$ & $\mathrm{~S}$ \\
\hline D1-FU & 21 & 11 & 231.00 & 0 & .00 & .00 & 11 & 32 & -4.291 & $<0.001$ & $\mathrm{~S}$ \\
\hline
\end{tabular}

Table: 8 Wilcoxon sign rank test for Extent of lesion

\begin{tabular}{|c|c|c|c|c|c|c|c|c|c|c|c|}
\hline \multirow{2}{*}{ Parameters } & \multicolumn{3}{|c|}{ Negative ranks } & \multicolumn{3}{|c|}{ Positive ranks } & \multirow{2}{*}{ Ties } & \multirow{2}{*}{ Total } & \multirow{2}{*}{$Z$ value } & \multirow{2}{*}{$P$ value } & \multirow{2}{*}{$\mathbf{R}$} \\
\hline & $\mathbf{N}$ & MR & SR & $\mathbf{N}$ & MR & SR & & & & & \\
\hline D1-D15 & 0 & .00 & .00 & 0 & .00 & .00 & 32 & 32 & .000 & $>0.001$ & $\mathrm{NS}$ \\
\hline D15-D30 & 22 & 11.50 & 253.00 & 0 & .00 & .00 & 10 & 32 & -4.690 & $<0.001$ & $\mathrm{~S}$ \\
\hline D30-FU & 9 & 5.00 & 45.00 & 0 & .00 & .00 & 23 & 32 & -3.000 & $<0.001$ & $\mathrm{~S}$ \\
\hline D1-FU & 31 & 16.00 & 496.00 & 0 & .00 & .00 & 1 & 32 & -5.568 & $<0.001$ & $\mathrm{~S}$ \\
\hline
\end{tabular}

